\title{
Assessing Teacher's Integration of Technology and Literacy in Elementary Science Classrooms in Kuwait
}

\author{
Fatimah Alhashem ${ }^{1} \&$ Ali Al-jafar ${ }^{1}$ \\ ${ }^{1}$ Scientific Consultant, Kuwait Foundation for the Advancement of Sciences (KFAS), Kuwait \\ Correspondence: Fatimah Alhashem, Scientific Consultant, Kuwait Foundation for the Advancement of Sciences \\ (KFAS), Kuwait. E-mail: falhashem80@gmail.com
}

Received: December 8, 2014 Accepted: March 20, 2015 Online Published: June 5, 2015

doi:10.5539/ass.v11n18p71 URL: http://dx.doi.org/10.5539/ass.v11n18p71

\begin{abstract}
The purpose of this study was to investigate experienced science teachers' perceptions regard integrating literacy and technology while teaching science at an elementary level. A concept map and rubric were developed based on the TPACK model to assess teachers' understanding and an in-depth interview technique was used to collect more data from the teachers. For the analysis, the concept map was graded based on the rubric and in-depth interviews were thematically analyzed. The data indicated that teachers have a negative perception about integrating technology and literacy in their classes, due to several barriers. This paper concludes with recommendations to facilitate the use of technology and literacy when teaching science in the elementary schools in Kuwait.
\end{abstract}

Keywords: integration, technological knowledge, TPACK, pedagogical knowledge, content knowledge, concept map, rubric, experienced teachers

\section{Introduction}

Nowadays, the situation of reforming, developing in education became part of the consist change that teachers need to adopt in terms of curriculum and assessment. More specifically, science teachers need to follow new methods while teaching science, such as scientific practices in the Next Generation Standards (Next Generation Science Standards, 2013) inquiry based. They also need to establish a base for scientific literacy. Thus, teachers need to provide obvious explanations so students meet the literacy demands of the science, which is important because it will help students express scientific phenomena and understand general topics discussed by scientists in real life (Norris, \& Phillips, 2003). However, in reality, teachers face many challenges in meeting this goal.

Like many other teachers in different countries, teachers in Kuwait face many barriers and challenges such as lack of support from the administration, an overloaded curriculum, teaching for testing, lack of resources, extra administrative work, extracurricular activities and events, and so on (Al-Sharaa, 2010; Ministry of Information, 2011). These difficulties can be a reason for leaving literacy behind or giving it little attention while teaching the main subject (Ministry of Information, 2011).

The purposes of speaking and listening, reading and writing remain central to being literate; however, we live in a modern society that has formed new literacy needs, especially with the use of technology (Bakia, Means, Gallagher, Chen, \& Jones, 2009). The importance of clear and efficient teaching of literacy through a rich and integrated program requires us to refocus teachers' literacy practice in our complex lifestyles (Baker, 2004). Teachers have started to depend more on using technology when planning their lessons, searching for facts, communicating with their students, and keeping up with the current published journals (Al-Qatari, 2011). The rationale for this research was based on the following reasons:

- The results of the Trends in International Mathematics and Science Study (TIMSS). Unfortunately, Kuwait scored very low in the international TIMSS examinations, ranking 48 out of a total of 342 points (Al-Qatari, 2011).

- The results of Progress in International Reading Literacy Study (PIRLS). Kuwait scored 419 points and was placed the $46^{\text {th }}$ out of the 49 countries (Al-Qatari, 2011).

Both results raised concerns about the quality of education for children in Kuwait in the areas of literacy and science. There are many approaches to investigating the low performance of the students but teachers are the 
single greatest influence in a student's academic performance, and they have to deal with many factors while teaching their subjects: core subject (science), literacy, pedagogy and technology.

This study investigated teachers' understanding and their perceptions about using literacy and technology while teaching science. The goal was to provide a closer look at how science teachers consider, implement, and integrate literacy and technology while teaching science at an elementary level. Thus the research questions were:

- How do science teachers in elementary schools use literacy and technology while teaching science?

- What are their attitudes toward using literacy and technology to enrich the science education curriculum?

\section{Literature Review}

\subsection{Science and Literacy}

Science and language cannot be separated from each other. When scientists and students explain phenomena, they use language to express new information and develop new concepts (Baker, 2004). Furthermore, reading and writing are major components of scientific literacy (Norris et al., 2003). The use of language is also part of developing new concepts and ideas (Vygotsky, 1962).

There are shared practices in both science and literacy in terms of learning. In learning science, students use the processes of scientific inquiry such as questioning, hypothesizing, collecting/analyzing data, and writing conclusions, which are similar to the literacy methods of purpose setting, expecting, sorting ideas, writing, and comprehending (Baker, 2004; Norris et al., 2003).

Recently, the National Research Council (NRC) of the National Academy of Sciences accomplished the first of two steps in the creation of the Next Generation Science Standards (NGSS). NGSS developed a Framework for K-12 Science Education and it was published in July 2011 (NRC Framework, 2012). The Framework states a vision in science education that involves students to manage relationship of three dimensions of learning: Science and Engineering Practices, Crosscutting Concepts, and Disciplinary Core Ideas (NRC Framework, 2012). The Framework also explained core ideas that all students should learn with accumulative depth from K-12 (NRC Framework, 2012).

The framework specifies for each disciplinary concept there has to be certain performance expectation with combining relevant practice of science or engineering in each grade level. That guideline of NGSS make them significant and different from standards documents. The NGSS claimed to be a guide for assessing students' science in both understanding of core ideas and their abilities to use the practices of science and engineering. Therefore, the new standards emphasis to teach students to be more active and engaged in science rather than memorizing scientific facts (NRC Framework, 2012).

Engagement in any of the science and engineering practices involves both scientific sense making and language use (American Association for the Advancement of Science, 2008). Practices link with one another in the sense-making process, which is a key attempt to help students to shift from their naive conceptions of the world to more scientifically, based conceptions.

Research has presented integrating literacy into content area teaching induce student's success in both science and language arts. For example, Amaral, Garrison, and Klentschy (2002) concluded that integrating the use of science notebooks in the elementary science curriculum lead to an improvement in student's achievement among English language learners (ELL). Their improvement took place in science, writing, reading, and mathematics (Amaral, Garrison, \& Klentschy, 2002).

To promote integration between science and literacy, we need to understand the importance of presenting children to texts and its information vocabulary and meaning of the texts. Researchers have recently paid significant attention to the absence of scientific texts in the reading lists of young children (Baker, 2004). Therefore, many studies started to focus on the integration between science and literacy (Norris et al., 2003) and it was found that supplementing science class with extra reading has a positive impact on learning. For instance, informational texts depend on a varied range of text structures such as cause/effect, compare/contrast, and problem/solution (Norris et al., 2003). It is good for students to be knowledgeable of these varied text structures and, in turn, build up their own base of writing strategies (Purcell-Gates, Duke \& Martineau, 2007). In addition, informational texts typically communicate information about the world beyond the child's home environment. Specifically, reading in science provides opportunities to expand students' vocabulary, knowledge and reading achievement (National Reading Panel, 2000). Another study showed that students who received both strategy instruction and extra reading about certain topics were more motivated than students who received strategy instruction alone (Guthrie, 2004). 


\subsection{Technology in Education}

There has been a revolutionary change in the practices and life styles of societies due to the use of technology. The alignment of rapid change and technology calls for a major change in our school curricula, in general, and, specifically, the science curricula. Although many teachers are using today's technologies in creative ways, these methods stay as exception but not a rule (Al-Ghanim, 2007). In the United States, classroom practice in terms of using technology has improved little from that of the mid-20th century in many schools (Bakia, Means, Gallagher, Chen, \& Jones, 2009). However, national surveys about teacher practices using technology revealed an increase in teacher use of technology as an efficiency tool, supporting their own work between 2005 and 2007 , but there has not been a significant difference in the level of assigning technology-based educational activities for students. (Bakia et al., 2009). In addition, technology implementation requires more than spending for resources but also continuing effort. Therefore, to make technology more productive in the class, educators need to understand the learning expectations, situations and the goals behind using technology.

\subsection{Context in Elementary School in Kuwait}

The situation is different from in public schools in Kuwait, students are taught science from first grade to fifth grade (Al-Ghanim, 2007). The Ministry of Education provides the six districts with funding for science labs, a school library, and technology (Al-Ghanim, 2007) and the Department of Curriculum and Research provides the curriculum and textbooks to all public schools. Supervisors design tests and assessment plans to explain the curriculum and the timeline to teach the textbook. Teachers have to follow the instructions of their supervisors and stick to the assessment plans. In a centralized system, teachers are left with few opportunities for creativity and less time to integrate literacy and technology into science (Al-Sharaa, 2010). Students who perceive solid facts will be less motivated, which will affect their understanding and, as a result, their performance will be low (Guthrie, 2004). To the date of this article, there are no standards for curriculum, teachers, or school leadership. The use of technology varies from school to another and limited to school resources or the voluntarily parents or school community.

\section{Conceptual Framework}

The Technological, Pedagogical, Content Knowledge (TPCK) framework builds on Shulman's $(1987,1986)$ explanation of Pedagogical Content Knowledge to describe how teachers' understanding of technologies and pedagogical content knowledge interact with one another to produce effective teaching with technology (Pierson, 2001).

In the model (Figure 1), there are three main components of knowledge: Content, Pedagogy, and Technology. They are all important in terms of interaction. These three parts of knowledge are represented as Pedagogical Content Knowledge (PCK), Technological Content Knowledge (TCK), Technological Pedagogical Knowledge (TPK), and Technological Pedagogical Content Knowledge (TPCK).

Content Knowledge refers to core knowledge for subject matter that is to be taught (Shin, 2009).Teachers need to know the science, language art, or math to teach their own subject. As Shulman (1986) explained, this contains knowledge of concepts, theories, ideas, and organizational frameworks, knowledge of proof, and practices.

Pedagogical Knowledge is defined as the knowledge of the techniques and practices of teaching and learning such as educational purposes, ethics, and skills (Shin, 2009). Teachers should know about learning theories, classroom management, lesson plans development and application, and student's assessment (Shin, 2009).

Lastly, Technological Knowledge allows teachers to accomplish different tasks using information technology and to develop different ways of achieving certain task (Niess, 2005). This concept never ends; it is continues process and keeps developing by time.

Teachers bring a unique blend of these three factors to each situation they meet and, therefore, there is not a single technological tool that can be applied for every teacher or every class. Teachers need to have the talent to find solutions by flexibly implementing the three components of content, pedagogy, and technology in specific settings. Thus, teachers have to show and put and effort by using cognitive skills not just in each of these main domains of $(\mathrm{T}, \mathrm{P}, \mathrm{C})$, but also in the way in which these domains connect so that they can be productive for teaching and learning.

In order to answer our research questions, we had to develop certain tools to assess teachers' use of literacy and technology while teaching science. Our conceptual framework was based on Technological Pedagogical Content Knowledge (TPCK). 


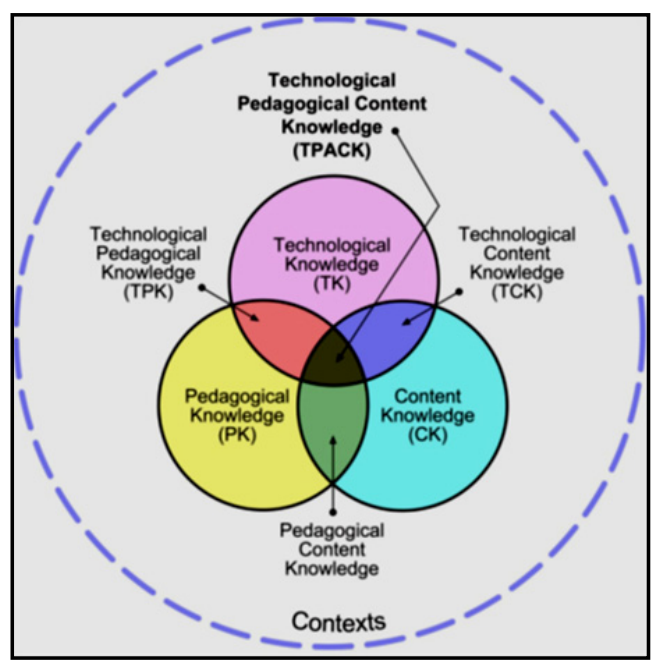

Figure 1. TPCK Model

\section{Method}

\subsection{Using Concept Map}

Concept maps are defined as graphical tools for organizing and demonstrating knowledge or ideas (Novak \& Musonda, 1991). A connecting line linking two concepts indicates concepts and the relationships between them. On every line, there are specific words/phrases to show or express the relationship between the two concepts (Novak \& Caas, 2008).

Concept maps were developed in 1972 in the course of Novak's research program at Cornell University, where he wanted to track and comprehend changes in science knowledge among children (Novak et al., 1991). During the course of the research work, the outcome and the results indicated that concept maps were useful not only to show the changes in children understanding topics, but usefulness of concept maps for others such as graduate students too. Concept maps were useful as a representation tool for expressing one's idea about certain topic.

A map provides an innovative means to establish quantitative data collection techniques, and allows researchers and participants to reflect on clarification of more analytical qualitative research on technology and literacy. In fact, concept maps have been used in longitudinal research to collect data on how understanding, visions, and perceptions can change or evolve over time (Kilic, Kaya, \& Dogan, 2004) since maps of a conceptual framework are, by nature, dynamic in the mind of the learner.

When a participant is generating a concept map, specific protocol must be followed because the concept map is more specific in structure than a mind map. The concept map production methodology includes a hierarchical presentation of general concepts on top leading to more specific concepts on the bottom; with linking words and directional arrows to show how specific concepts are related and interrelated (Novak et al., 2008).

The structure of concept maps is an integral part of their assessment by experts when using the concept map to demonstrate understanding. Novak and Gowin (1984) recommended that the subject matter expert score the maps based on the number of valid propositions, levels of hierarchy, number of branches and cross-links. If the participant generates their own list of terms, analysis may take longer, since the initial term lists generated by participants are highly individual. Termed an "embarrassment of riches" (Chenail, 1995, p. 2), interpretation can become difficult due to the highly individualized nature of each concept map created. One solution has been to limit maps to one page, or provide a finite list of terms to participants creating concept maps (Wheeldon, 2007) along with clear instructions and an exemplar map.

Refinements in the scoring of concept maps have included similar structural scoring systems based on their physical characteristics (Turns, Atman, \& Adams, 2000). Some have used down scales to score the quality of concepts and schemes in the maps (Rye \&Rubba, 2002) or whether participants correctly identified concepts vs. sub-concepts (Bayram, 1995) within the map structure itself. Another scoring system was developed to compare experts in learning based on the comparison of concepts maps between a novice and expert (Ruiz-Primo, Shavelson, \& Schultz, 2001). It seems there are many different ways to interpret and score concept maps, and these methods are tailored to the purpose of the study as well as the method of data collection. 


\subsection{Assessing TPCK Based on Exemplary Concept Maps}

The next task was to create an exemplary concept map to use as criterion reference for rubric creation and, eventually, the scoring of the five maps. A team consisting of four veteran science teachers, all with at least 20 years' experience teaching science at elementary level, came to an agreement on the structure of the exemplary concept map based on the education system in Kuwait. The twelve terms they agreed on, along with a set of appropriate linking words, are as follows:

The term nonfiction 'children literature in science education' was a common thread across all scientific disciplines and was deemed most important, placing it at the top of the exemplary concept map. Below that, the terms 'school curricula' which it means the activity that happen in school but are not part of the curriculum and 'extra- curricular' should be connected. In a lower grouping, the terms 'school library', and 'e-learning' were also linked. At the terminal end of the map are the terms 'content knowledge' (textbook and workbook), technological knowledge (online games and scientific websites for children), and 'pedagogical knowledge' (glossary, scientific sorties, and picture books).

When creating the rubric to score the concept maps, it was decided that both the association between the concepts and organization of the concept map should have equal weight since the list of terms to be organized into the concept map was supplied to the participants. This decision gave the concepts connectivity and the organization of the concept map an equal weight of 12/28 points. Since the participants themselves added the linking terms, this was deemed of less importance in the overall organization and conceptual framework, and was only given a weight of $4 / 28$ points.

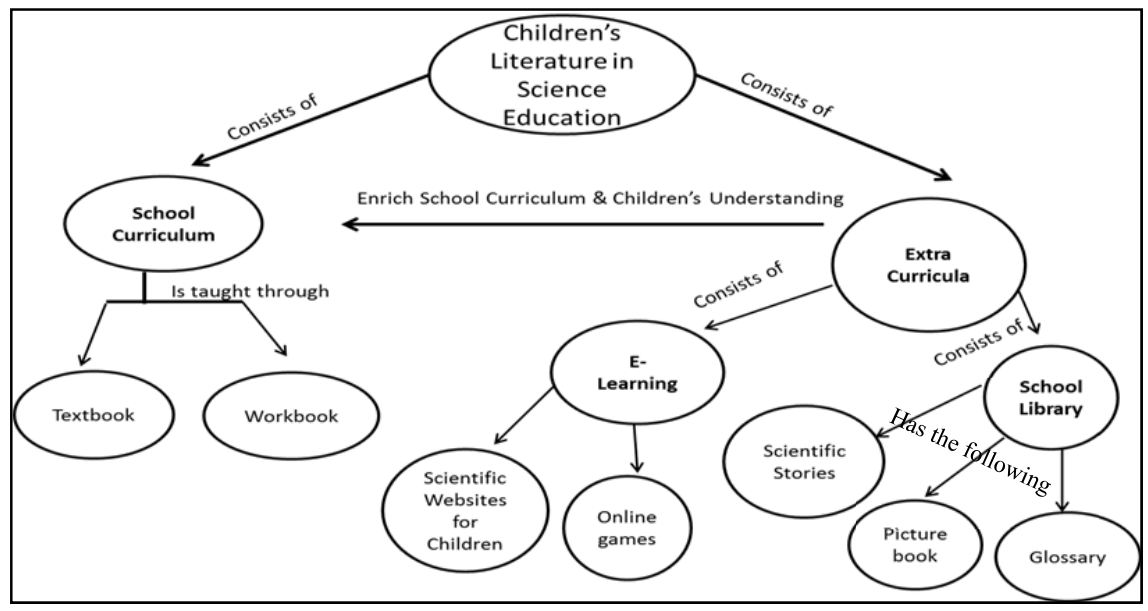

Figure 2. Exemplary Concept Map

Table 1. Rubric

\begin{tabular}{|c|c|c|c|c|c|c|}
\hline & Category & Exemplary 4 & Exceeds Standard 3 & Meets Standard 2 & Below Standard 1 & Points \\
\hline $\begin{array}{c}\text { Concepts } \\
1 . \\
2 . \\
3 .\end{array}$ & $\begin{array}{l}\text { Literacy } \\
\text { Science } \\
\text { Technology }\end{array}$ & $\begin{array}{l}\text { children literature at top of } \\
\text { the page, all other terms } \\
\text { below } \\
\text { All } 4 \text { terms linked }\end{array}$ & $\begin{array}{l}\text { children literature as a } \\
\text { major heading } \\
3 / 4 \text { terms are linked } \\
\text { appropriately } \\
3 / 4 \text { terms are linked }\end{array}$ & $\begin{array}{l}\text { More than one } \\
\text { linkage } \\
\text { 2/4 terms are linked } \\
\text { appropriately } \\
2 / 4 \text { terms are linked } \\
\text { appropriately }\end{array}$ & $\begin{array}{l}1 \text { or } 0 \text { terms are linked } \\
\text { appropriately } \\
1 \text { or } 0 \text { terms are linked } \\
\text { appropriately }\end{array}$ & 12 \\
\hline $\begin{array}{r}\text { Organizat } \\
1 . \\
2 . \\
3 .\end{array}$ & $\begin{array}{l}\text { tion } \\
\text { Knowledge of relationships } \\
\text { among concepts } \\
\text { Horizontal relationships } \\
\text { (network organization) } \\
\text { Vertical relationships } \\
\text { (hierarchical organization) }\end{array}$ & $\begin{array}{l}\text { Identifies all important } \\
\text { concepts and shows an } \\
\text { understanding of linkage } \\
\text { between relationships } \\
\text { More than } 2 \text { appropriate } \\
\text { horizontal relationships } \\
3 \text { vertical relationships are } \\
\text { appropriate }\end{array}$ & 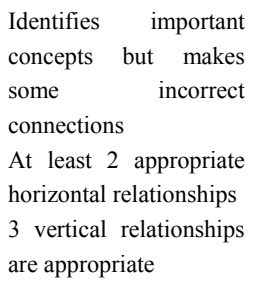 & $\begin{array}{l}\text { Makes many } \\
\text { incorrect connections } \\
\text { Only } 1 \text { horizontal } \\
\text { relationship } \\
2 \quad \text { vertical } \\
\text { relationships } \\
\text { branches }\end{array}$ & $\begin{array}{l}\text { Fails to use any } \\
\text { appropriate concepts, } \\
\text { does not make any } \\
\text { connections } \\
\text { No horizontal } \\
\text { relationships present } \\
1 \text { vertical relationship } \\
\text { branch }\end{array}$ & 12 \\
\hline Linking $\mathrm{V}$ & Nords & 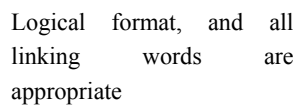 & $\begin{array}{l}\text { Most linking words are } \\
\text { appropriate }\end{array}$ & $\begin{array}{l}\text { At least half of the } \\
\text { linking words are } \\
\text { appropriate }\end{array}$ & $\begin{array}{l}\text { Minority of linking } \\
\text { words are appropriate }\end{array}$ & 4 \\
\hline
\end{tabular}




\subsection{In-depth Interview}

To assure that researchers understand the teachers an in-depth interview was conducted to clarify the concept maps. The feedback from the interview helped in assessing the concept maps. The in-depth interviews were part of the assessment methodology that researcher used to enhance and assure the reliability of what teachers are trying to express. Questions were developed and merged from both the rubric, and the current situation of science education at the elementary level. The interview questions focused on three main factors school library and extra curriculum activities, use of technology, and sources of curriculum (Table 3). The in-depth interview helped in understanding and modifying the rubric for further research in the future, and in evaluating the current situation of science and literacy.

Table 3. The interview questions

\begin{tabular}{l}
\hline School library and Extra Curriculum \\
- How does the books in the school library help in teaching science? \\
- $\quad$ Do you implement science fiction in your curriculum? If so how? If not, why? \\
\hline The Use of Technology \\
- $\quad$ Does your school support the use of technology if so how? \\
- How much do use technology while teaching science? \\
- $\quad$ To what websites do you use to enrich students understanding in science? \\
- How can a teacher develop the use of varied sources of books and internet to teach science? \\
\hline Sources for Curriculum \\
- What are the resources for your curriculum besides your textbook? \\
- What resources do you use to write your worksheets/ tests / quizzes?
\end{tabular}

\subsection{Procedure}

Researchers contacted six experienced elementary science teachers from the six school districts in Kuwait; only four volunteered to complete the study. The office of senior superintend helped in selecting the best teachers. Women mostly teach the elementary public schools and therefore all of our participants were female teachers. Teachers were asked to draw concept maps about how they view literacy, science, and technology together. This study utilized the concept map and its rubric and an in-depth interview in order to have an understanding about teachers' usage of literacy and technology while teaching science to elementary students. These in-depth interviews investigated teachers about their perspectives about pedagogical content knowledge, use of technology in teaching, and science education. As well as some general questions about their teaching assignment and the professional structure of their school and department.

Within the written instructions to teachers on creating, the concept maps were specific instructions on how to create concept maps in general as well as a specific example of a concept map that uses a non-science topic. The teacher then created a concept map using the given terms and sent it in either hard copy or scanned and faxed to the researchers.

\section{Results}

Table 4 is a summary of the results of the concept maps, the teachers' backgrounds, and the responses to questions about literacy and technology integration with science:

- How do science teachers in elementary schools use literacy and technology while teaching science?

- What are their attitudes toward using literacy and technology to enrich science education curriculum?

The concept maps scoring reliability issue was very important. Both researchers cross-scored the concept maps and compare their scorings. Then, senior superintendent revised the scores and discussed it with the researchers. Moreover, for better understanding, teachers were interviewed after the completion of their concept maps.

In the in-depth interview, teachers were very expressive about their situation and reflected on their experiences while teaching science. Researchers decided to pair them into two categories: head department teachers and experienced teachers. 
Table 4. Data analysis

\begin{tabular}{|c|c|c|c|c|}
\hline & Eman & Najowa & Ghadeer & Anood \\
\hline \multicolumn{5}{|l|}{ Teacher's Background } \\
\hline Title & Head department & Experienced teacher & Experienced teacher & Head department \\
\hline Major & $\begin{array}{l}\text { Elementary science } \\
\text { education }\end{array}$ & Biology & $\begin{array}{l}\text { Elementary science } \\
\text { education }\end{array}$ & $\begin{array}{l}\text { Elementary } \\
\text { science education }\end{array}$ \\
\hline Years of experience & 24 & 15 & 10 & 12 \\
\hline \multicolumn{5}{|l|}{ Concept Map Score } \\
\hline Concept map score & $50 \%$ & $55 \%$ & $66 \%$ & $72 \%$ \\
\hline \multicolumn{5}{|c|}{ Teacher response to the in-depth interview } \\
\hline \multicolumn{5}{|l|}{ Library and extra books } \\
\hline Use of school library / updated & No & No & No & No \\
\hline $\begin{array}{lc}\text { Scientific fiction and } \\
\text { imagination in science }\end{array}$ & No & Yes & Yes & Yes \\
\hline Source of books & Her own & Her own & Her own & Her own \\
\hline \multicolumn{5}{|l|}{ Use of technology } \\
\hline Use of technology in science & Yes & Yes & Yes & Yes \\
\hline Valid educational websites & $\begin{array}{l}\text { No, just the Google } \\
\text { engine search }\end{array}$ & $\begin{array}{l}\text { Yes, but most of } \\
\text { them are in English } \\
\text { and she translated } \\
\text { them }\end{array}$ & $\begin{array}{l}\text { Yes but needed to } \\
\text { translate }\end{array}$ & $\begin{array}{l}\text { Google engine and } \\
\text { some English } \\
\text { websites }\end{array}$ \\
\hline Source of Technology & Teacher's own tools & Teacher's own tools & Teacher's own tools & $\begin{array}{l}\text { Teacher's } \\
\text { tools }\end{array}$ \\
\hline $\begin{array}{l}\text { Students use technology while } \\
\text { learning science }\end{array}$ & All the time & All the time & All the time & All the time \\
\hline \multicolumn{5}{|l|}{ Enrich school Curriculum } \\
\hline $\begin{array}{lll}\text { School textbook } & \text { support } \\
\text { resources } & & \\
\end{array}$ & Internet & Teachers' guide & $\begin{array}{l}\text { Teachers' guide and } \\
\text { Internet }\end{array}$ & Internet \\
\hline $\begin{array}{l}\text { Enrich school curriculum with } \\
\text { extra- curricular resources }\end{array}$ & $\begin{array}{l}\text { Very limited due to } \\
\text { the overloaded school } \\
\text { curriculum }\end{array}$ & $\begin{array}{l}\text { Department scientific } \\
\text { discussion/ and } \\
\text { enrich students with } \\
\text { new updated } \\
\text { information }\end{array}$ & $\begin{array}{l}\text { Update herself with all } \\
\text { new ideas about science } \\
\text { and help in teaching in } \\
\text { class }\end{array}$ & $\begin{array}{l}\text { Help teachers and } \\
\text { mentees in her } \\
\text { department, enrich } \\
\text { students with extra } \\
\text { facts about science }\end{array}$ \\
\hline
\end{tabular}

\subsection{Head Department Teachers}

Teachers discussed some of the barriers that prevent them from being creative. They all agreed that the science curriculum is very developed, but there are many topics to cover. This issue leaves limited space for extra curriculum or implementing technology, or integrating literacy into science, as they all responded.

Eman elaborated about the administrative load that prevents her from doing any extra activity with her students. She said that she missed the days where she used to do more activities such as reading with her students while teaching, before becoming a head department. Her time is split between administrative work and mentoring teachers, and the rest for teaching her own classes "with the endless curriculum," as she described. Eman also finds school resources are outdated. She said:

"The school library, for example, has old books, colorless, and not very attractive to children. I have to buy my own books and some equipment too. I use my own iPad to show some pictures to my students."

Anood also suffers from lack of time as a department head. She also suffers from a lack of support in terms of school resources. Anood said that the school administration should focus on enriching schools with more developed resources that are appropriate to the modern life style. She mentioned materials are needed for each classroom, such as smart boards, iPads, and projectors. Anood finds it easy to integrate literacy into science if technology is available. She said there are many barriers such as:

"The books in the library are old; I had to build my own library with the support of my science teachers in the department. We use our own technology... the use of technology is limited still because the school curriculum has many topics, and I cannot manage too many things. You know there are experiments, worksheets, tests, and grading... it is not easy to do all of these things as well as my administrative work."

\subsection{Experienced Teachers}

Najwa finds technology and the uses of Internet are becoming the most powerful sources for both teachers and students; however, the school curriculum is still dense with many comprehensive topics. Najwa also explained that teachers are very cautious in terms of integrating literacy into science because supervisors from the districts 
usually want teachers to stick to the curriculum and teach from the textbooks only. She also said that she brings her own laptop and Wi-Fi to school for both teaching and preparing her own work. Najwa elaborated also that there is only one desktop computer to use in the science department, and she said that she would not waste her time on that "useless desktop."

"Students are de-motivated, and they want modern methods that speak to them. They keep asking me why we are doing this experiment and, due to the lack of time, I explain a little bit to them ... if I had more time, I would read with them or ask them to use the Internet to search for a topic, and even the Internet sources, most of them are in English. The school needs more Arabic resources that students are familiar with... I have no problems translating stuff, but children are limited with few resources if they are going to use Google or App store."

Ghadeer's "nightmare," as she expressed it, was the supervisors. She said that the "supervisors want us to teach the textbook as a holy book." She mentioned that there is a gap between the supervisors' generation and the students'. Students have changed because of technology. Students like to search for facts rather than reading about the whole topic.

"If I teach from the textbook, all the children will be bored. I believe every teacher should have her own touch for each class she teaches. I have noticed that many of my students have their own iPads, and I requested from the parents to allow them to use it in the classroom. We downloaded some Apps from the App store, it saved time, and children were motivated to use technology in learning. I travel to Dubai to buy books from there... book resources are very limited in school and the whole country too. Reading is not a favorite thing for children nowadays. They want easy facts from the web."

\section{Discussion and Conclusion}

In this paper, the focus was on assessing teacher integration of literacy and technology into elementary science. We have developed a concept map followed by a rubric to assess teachers' integration. Then, in-depth interviews took place after the completion of concept map by teachers. We evaluated the concept map, analyzed interviews, and coded them. We were trying to evaluate how teachers integrate literacy, technology, and their attitude about the integration.

The concept map scores were very low, with the highest score being $72 \%$. We cannot generalize based on assessing concept maps of four teachers; however, this result could tell us something about them. Teachers might be limited to teaching the school curriculum, which could limit their vision about how to integrate science with other topics such as literacy. The school paradigm has shifted toward the curriculum and this leaves teachers with fewer options regarding extra-curricular activities and other variables while teaching science in schools.

In terms of the interview analysis, it seems that the school curriculum is not parallel with technology, which could create a barrier to teachers keeping up and motivating students to do science. Libraries are outdated too and need major reforms by providing books and applying technology. A mile-long, inch-deep curriculum may not teach students everything about science while giving teachers' space with fewer topics might help.

It seemed from both concept maps and interviews that teachers need more space to add their own touch of creativity while teaching their classes. The results have shown that teachers have limited vision about how to integrate technology and literacy based the conceptual framework in this paper. When they were asked to briefly state why they need to apply technology or literacy in their teaching, most of the teachers maintain that they are tools for instruction; they fail to relate them to pedagogy or identify how they will help them to improve their teaching or support students' learning. It is important in classroom management that teachers know how to integrate and apply it for not only technology and literacy but many other subjects.

Next, teachers also represented an example of lacking to connect the pedagogical knowledge while using technology or literacy in teaching science. Due to the situations that were experiencing, teachers were unable to explore the process of technology integration. There were also limited in methods that it can be effectively accomplished. Teachers were limited in developing or selecting an appropriate to use technologies or books with fixed curriculum and overloaded lessons. The process of exploring the relationship between technology and literacy while teaching science will require critical thinking and more effort and planning. The teacher were expressing some demotivation and lack of interest due to the structure of the curriculum.

In summary, in order to integrate technology and literacy in Kuwait, there is a need to renovate the educational curriculum to ensure the teacher has the flexibility to use technology or at least be able to integrate different topics while teaching science. Moreover, the structure of analysis of the program ought to change and empower teachers to teach what is relevant to the student at any given time. This is because technology keeps on changing, 
and it would be expensive to keep changing the curriculum. Lastly, the school systems should adopt technology to ease the difficulties of buying and preserving books and encourage teachers to use them while teaching science.

\section{Recommendations}

Our recommendations for future actions and further studies are:

- Conduct another study with larger number of teachers.

- We could track pre-service teachers and measure their understanding over time using the concept map as an assessment tool.

- Provide a space for teachers to add their own teaching method and allow supervisors to guide rather than inspect and track curriculum.

- Determine the current needs for more advanced classrooms and libraries in terms of technology in Kuwait's elementary schools.

- Identify priorities of reform in science education and development strategies, and other interventions that will link literacy and technology education to job creation and appropriate career skills.

- Provide appropriate professional development for teachers.

\section{References}

Al-Ghanim, K. (2007). Study: Students failure at public schools in Kuwait costing the country huge money. Kuwait News Agency KUNA. Retrieved from http://www.kuna.net.kw/newsagenciespublicsite/Article Details.aspx?languag $=$ ar\&id $=1861893$.

Al-Qatari, H. (2011). Kuwait facing national educational disaster. Tribune Business News. Tacoma Washington

Al-Sharaa, I. (2010). MoE, Microsoft launch hi-tech schools project in Kuwait. Kuwait Times. Retrieved from http://issuu.com/kuwaitnews/docs/kt20101202

Amaral, O. M., Garrison, L., \& Klentschy, M. (2002). Helping English learners increase achievement through inquiry-based science instruction. Bilingual Research Journal, 26, 213-240. http://dx.doi.org/10.1080/ 15235882.2002.10668709

American Association for the Advancement of Science. (2008). Benchmarks for science literacy project 2061. Washington, DC: Author.

Association for the Advancement of Computing in Education (AACE).

Baker, L. (2004). Reading comprehension and science inquiry: Metacognitive connections. In W. Saul (Ed.), Crossing borders in literacy and science Instruction (pp. 239-257). Newark, DE: International Reading Association. http://dx.doi.org/10.1598/0872075192.13

Bakia, M., Means, B., Gallagher, L., Chen, E., \& Jones, K. (2009). Evaluation of the enhancing education through technology program: Final report. Washington, D.C.: U.S. Department of Education.

Bayram, S. (1995). The effectiveness of concept and software mapping for representing student data and process schema in science (Unpublished master's thesis). University of Pittsburg, PA.

Bull, G., \& Kajder, S. (2004). Digital storytelling in the language arts classroom. Learning \& Leading with Technology, 32(4), 46-49.

Buzan, T. (1974). Use your head. London. UK: BBC Books.

Chenail, R. J. (1995). Presenting qualitative data. The Qualitative Report, 2(3). Retrieved from http://www.nova.edu/ssss/QR/QR2-3/presenting.html

Foy, P., Arora, A., \&Stanco, G.M. (Eds.). (2013). TIMSS 2011 User guide for the international database. Chestnut Hill, MA: Boston College.

Guthrie, J. T. (2004). Teaching for literacy engagement. Journal of Literacy Research, 36(1), 1-28. http://dx.doi.org/10.1207/s15548430jlr3601_2

Hyland, K. (2010). Constructing proximity: Relating to readers in popular and professional science. Journal of English for Academic Purposes, 9(2), 116-127. http://dx.doi.org/10.1016/j.jeap.2010.02.003

Kilic, Z., Kaya, O. N., \& Dogan, A. (2004). Effects of students' pre- and post- laboratory concept maps on students' attitudes toward chemistry laboratory in university general chemistry. Paper presented at the18th 
International Conference on Chemical Education, Istanbul, Turkey.

Ministry of Information. (2011). Ministry of Education. Retrieved from http://www.kuwait-info.com/ministryof-education.html

Mishra, P. (1999/2004). The role of abstraction in scientific illustration: Implications for pedagogy. Journal of Visual Literacy, 19(2), 139-158. To be reprinted in C. Handa (Ed.), Visual rhetoric in a digital world: A critical sourcebook. Boston, MA: Bedford/St. Martin's Press.

Mishra, P., \& Koehler, M. (2007). Technological pedagogical content knowledge (TPCK): Confronting the wicked problems of teaching with technology. In C. Crawford et al. (Eds.), Proceedings of Society for Information Technology and Teacher Education International Conference 2007. Chesapeake, VA: Association for the Advancement of Computing in Education 2214-2226.

Moller, K. J., \& Hug, B. (2006). Connections across literacy and science instruction in early childhood education: Interviewing disciplines in pre-service education. In J. V. Hoffman, D. L. Schallert, C. M. Fairbanks, J. Worthy, \& B. Malocj (Eds.), 55th Yearbook of the National Reading Conference (pp. 195-211). Oak Creek, Wisconsin: National Reading Conference.

National Reading Panel. (2000). Teaching children to read: An evidence-based assessment of the scientific research literature on reading and its implications for reading instruction [on-line]. Retrieved from http://www.nichd.nih.gov/publications/nrp/report.cfm

National Research Council (NRC). (2012). A Framework for K-12 Science Education: Practices, Crosscutting Concepts, and Core Ideas. Committee on a Conceptual Framework for New K-12 Science Education Standards. Board on Science Education, Division of Behavioral and Social Sciences and Education. Washington, DC: The National Academies Press.

Next Generation Science Standards. (2014, July 5). Next Generation Science Standards. Web.

Niess, M. L. (2005). Preparing teachers to teach science and mathematics with technology: Developing a technology pedagogical content knowledge. Teaching and Teacher Education, 21(5), 509-523. http://dx.doi.org/10.1016/j.tate.2005.03.006

Norris, S. P., \& Phillips, L. M. (2003). How literacy in its fundamental sense is central to scientific literacy. Science Education, 87, 224-240. http://dx.doi.org/10.1002/sce.10066

Norton-Meier, L., Hand, B., Cavagnetto, A., Akkus, R., \& Gunel, M. (2009). Pedagogy, implementation and professional development for teaching science literacy: How students and teacher know and learn. In M. C. Shelley II, L. D. Yore, \& B. Hand (Eds.), Quality research in literacy and science education: International perspectives and gold standards. Dordrecht, Netherlands: Springer. http://dx.doi.org/10.1007/978-14020-8427-0_9

Novak, J. D. (1998). Learning. Creating, and Using Knowledge: Concept Maps as Facilitative Tools in Schools and Corporations. Mawah, NJ: Lawrence Erlbaum.

Novak, J. D., \& Cañas, A. J. (2008). The Theory Underlying Concept Maps and How to Construct Them. Technical Report IHMC CmapTools 2006-01 Rev 01-2008, Florida Institute for Human and Machine Cognition.

Novak, J. D., \& Gowin, D. B. (1984). Learning How to Learn. New York, NY: Cambridge University Press. http://dx.doi.org/10.1017/CBO9781139173469

Novak, J. D., \& Musonda, D. (1991). A twelve-year longitudinal study of science concept learning. American Educational Research Journal, 28(1), 117-153. http://dx.doi.org/10.3102/00028312028001117

Peacock, A., \& Gates, S. (2000). Newly qualified primary teachers' perceptions of the roles of text materials in teaching science. Research in Science \& Technological Education, 18(2), 155-171. http://dx.doi.org/10.1080/713694982

Pierson, M. (2001). Technology integration practice as a function of pedagogical experts. Journal of Research on Computing in Education, 33(5).

Purcell-Gates, V., Duke, N., \& Martineau, J. A. (2007). Learning to read and write genre-specific texts: Roles of authentic experience and explicit teaching. Reading Research Quarterly, 42(1), 8-45. http://dx.doi.org/10.1598/RRQ.42.1.1

Rice and Rainsford. (1996). Using children's trade books to teach science: Boon or boondoggle. Paper presented 
at the annual meeting of the National Association for Research in Science Teaching, St. Louis, MO.

Rice, D. C. (2002). Using trade books in teaching elementary science: Facts and Fallacies. The Reading Teacher, 55(6), 552-565.

Ruiz-Primo, M., Shavelson, R. J., Li, M., \& Schultz, S. E. (2001). On the validity of Cognitive interpretations of scores from alternative concept-mapping Techniques. Educational Assessment, 7, 99-141. http://dx.doi.org/10.1207/S15326977EA0702_2

Rye, J. A., \& Rubba, P. A. (2002). Scoring concept maps: An expert map-based Scheme weighted for relationships. School Science \& Mathematics, 102(1), 33-45. http://dx.doi.org/10.1111/j.1949-8594.2002. tb18194.x

Shin, T. S. (2009). Examining preservice teachers' development of technological pedagogical content knowledge in an introductory instructional technology course. In I. Gibson, R. Weber, K. McFerrin, R. Carlsen, \& D. A. Willis (Eds.), Society for Information Technology and Teacher Education International Conference book, 2009. Chesapeake, VA.

Shulman, L. S. (1986). Those who understand: Knowledge growth in teaching. Educational Researcher, 15, 4-14. http://dx.doi.org/10.3102/0013189X015002004

Shulman, L. S. (1987). Knowledge and teaching: Foundations of the new reform. Harvard Educational Review, 57, 1-22. http://dx.doi.org/10.17763/haer.57.1.j463w79r56455411

Turns, J., Atman, C., \& Adams, R. (2000). Concept maps for engineering education: A cognitively motivated tool supporting varied assessment functions. IEEE Transactions on Education, 43, 164-173. http://dx.doi.org/10.1109/13.848069

Vygotsky, L. S. (1962). Thought and Language. Cambridge MA: MIT Press.

Wheeldon, J. (2007). Bringing British Columbia to Latvia: Canadians reflect on expert designation in international criminal justice project. Burnaby, British Columbia, Canada: School of Criminology, Simon Fraser University.

Yager, R. E. (2004). Science is not written, but it can be written about. In W. E. Saul (Ed.), Crossing borders in literacy and science instruction. Arlington, VA: NSTA. http://dx.doi.org/10.1598/0872075192.5

\section{Copyrights}

Copyright for this article is retained by the author(s), with first publication rights granted to the journal.

This is an open-access article distributed under the terms and conditions of the Creative Commons Attribution license (http://creativecommons.org/licenses/by/3.0/). 